\title{
Introduction: Collaborations between scientists and \\ rhetoricians of science/technology/medicine
}

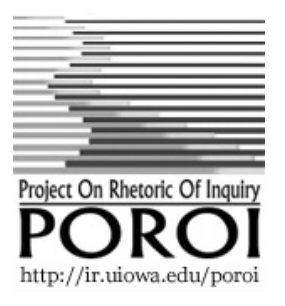

Jean Goodwin

Iowa State University

Ames, Iowa USA

Poroi 10,1(January 2014)

Keywords: rhetoric, rhetoric of science, science communication, collaboration, interdisciplinarity

\section{Introduction}

As the old Chinese curse puts it, rhetoricians of science are living in interesting times. Suddenly, it seems, we are much needed. The science establishment appears to be worried about slipping from their rightful place. Improved communication has emerged as a key perceived solution to this alleged problem; it promises to maintain the public's trust in the scientific enterprise and the authority of science in policy-making.

The signs of this concern for the public face of science are many. Funding agencies have been asking scientists to interact with audiences beyond their disciplines. For NSF, this has meant ramping up the requirement that all grantees demonstrate broader impacts of funded work, including outreach through informal science education, contacts with policy-makers, or other forms of public engagement. The NIH likewise has established a new emphasis on "translational research" to ensure that the science it funds pays off in terms of improved health; this initiative supports communication programs promoting behavioral changes. 
Resources to help scientists build their communication skills have also been proliferating. At least a book a year promises to help scientists get along better with publics and the press. The NSF has sponsored a communication road show that has probably visited close to three dozen states by now. Over the course of the two day workshop, three prominent science journalists try to lure scientists into "becoming the messenger" for science by blogging, tweeting and being available to reporters.

There has even been a welcome for communication research; a welcome, at least, for our social scientific colleagues. The National Academy of Sciences has dedicated prestigious Sackler colloquia to the "science of science communication" for two years running. Papers on science communication have long been a staple at the AAAS conference, and national science societies have been following suit. The American Geophysical Union, for example, has had conference panels on communication, has instituted a climate communication prize, and ran an entire conference on climate communication in the summer of 2013. And the American Meteorological Society has been partnering with NCA to bring communication scholars to their convention.

Rhetoricians of science, technology and medicine, for their part, are in principle ready to help. The turn towards public rhetorics of science documented in Condit et al.'s (2012) survey of the literature has flowered into a commitment to transition from rhetorical theory to rhetorical practice. This emerged as a significant theme in the 2012 ARST preconference dedicated to reflection on past accomplishments and agenda-setting for the future. At that event, Carl Herndl (2013) described his university's program for 'build[ing] interdisciplinary alliances, engag[ing] with our colleagues in science to help manage uncertainty and the threat of ecocide, and develop[ing] specific strategies and tools to put into practice our disciplinary intentions to make a difference," especially in the areas of science policy, citizen participation, and data visualization. Leah Ceccarelli (2013) issued a challenge to the community, calling for "scholarly reflection...on how rhetoricians of science and technology can best facilitate translation of basic research on the rhetoric of science and technology into improved public communication of science and technology."

So it is the best of times; an age where scientists and rhetoricians are enthusiastic about collaborating with each other. It is also the worst of times-or at least, it is the same old times. What scientist colleagues ask rhetoricians of science to do does not, let's say, always draw from the full 
range of what we could and would like to contribute. Here are some of the typical requests I receive from colleagues each semester:

Could you lead a workshop and get my students to avoid jargon when talking with the public? Teach them how to make attractive PowerPoint slides, too. And while you're at it, work on their delivery - their delivery is bad, very bad.

I need a website/ magazine article/ press release for my research. Can you help?

What do I need to say to the public so they'll accept [insert favored technology or policy]. Can you do some surveys to find out?

The causes of the current mis-match between scientists' perceived needs and rhetoricians' available expertises run deep. On the science side, even the best-intentioned scientists sometimes adopt a "conduit" model of communication, looking to rhetoricians for communication techniques to wrap around the science content they will provide. Some also implicitly endorse a "deficit" model, speaking as if all that is needed to put policy, science funding or technology acceptance on the right course is to provide the public with sound information. Finally, many scientists are comfortable with the empirical methods of our social science colleagues; humanistic methods-not so much.

Scientists seem to be looking to rhetoricians of science to be newmedia savvy avatars of the Gorgias fashioned by Plato: communicators who are more persuasive on technical subjects than the experts, at least with ignorant audiences. Contemporary rhetoricians, for their part, are likely to object. At the same time, rhetoricians also bear responsibility for the preconceptions they bring to dialogue with scientists. Celeste Condit (2013) made this point strongly at the 2012 ARST preconference, reminding rhetoricians to restrain their "science [is] bad"/ "science [is] too powerful" talk and accept that scientists and rhetoricians need each other.

The purpose of the "Rhetoric \& Outreach" panel at the 2013 ARST preconference was to address these difficulties by showcasing existing models of innovative and productive scientist/ rhetorician collaborations. 
In particular, the work described in the following reports has been funded - a strong signal that rhetoricians participated as full participants in the projects. Each panelist was invited to describe his or her project, its costs and benefits, and in particular, what I call (following Henry W.

J ohnstone, J r., 1991), the "wedge." What in each case did rhetoricians have to offer to scientist colleagues? What was the wedge that opened up cracks in the mutual mis-expectations sketched above?

Three of these reports demonstrate ways in which rhetoricians can advance their work by adapting to scientists' expectations of rhetoricians. Kenny Walker takes the traditional role of rhetor-now "science communicator" - and adds humanistic depth about uncertainty to the mix of journalists, artists, social scientists and corporate communicators in his program. My report describes a project which leverages existing interest in ethics and communication to provide a richer, more rhetorically based pedagogy for STEM graduate students. Sara Parks shows how an "embedded rhetorician" can develop a communication outreach program for a Big Science project while advancing her own research.

Two of these reports go on to show how challenging the expectations can-over the long run-lead to innovative partnerships. J ohn Rief uses the architectonic art of rhetoric to identify and build across gaps, connecting all stakeholders in the healthcare system. And Caroline Gottschalk Drushke demonstrates how sustained engagement opens possibilities for truly interdisciplinary research/practice projects linking scientists, rhetoricians and community members.

As is often the case for rhetorical scholarship, the projects collected here are intensely local, taking advantage of the "available means" at diverse institutions and career stages. Nevertheless, the panel participants hope to inspire further efforts and to continue the general conversation on public scholarship in the rhetoric of science, technology and medicine.

\section{REFERENCES}

Ceccarelli, Leah. (2013). To Whom Do We Speak? The Audiences for Scholarship on the Rhetoric of Science and Technology. Poroi 9(1). Retrieved from http://ir.uiowa.edu/cgi/viewcontent.cgi?article=1151\&context=poroi 
Condit, Celeste M. (2013). "Mind the Gaps": Hidden Purposes and Missing Internationalism in Scholarship on the Rhetoric of Science and Technology in Public Discourse. Poroi 9(1). Retrieved from http://ir.uiowa.edu/cgi/viewcontent.cgi?article=1150\&context=poroi

Condit, Celeste M., Lynch, J ohn, \&Winderman, Emily. (2012). Recent rhetorical studies in public understanding of science: Multiple purposes and strengths. Public Understanding of Science, 21(4), 386- 400.

Herndl, Carl G., \&Cutlip, Lauren L. (2013). "How can we act?" A Praxiographical Program for the Rhetoric of Technology, Science, and Medicine. Poroi 9(1). Retrieved from http://ir.uiowa.edu/cgi/viewcontent.cgi?article=1163\&context=poroi

J ohnstone, Henry W., J r. (1991). Philosophical argument and the rhetorical wedge. Communication \& Cognition, 24(1), 77-92. 